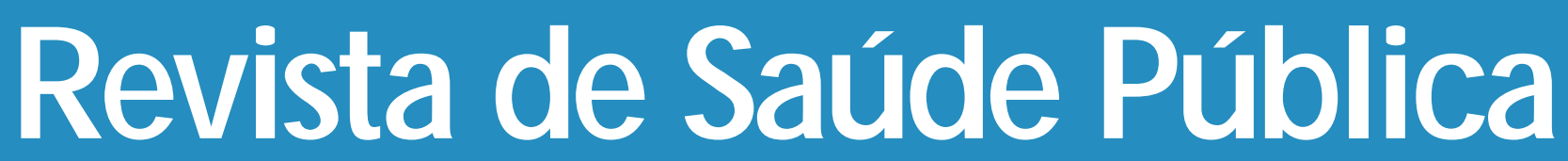

$\begin{array}{lllllll}J & \mathbf{O} & \mathbf{U} & \mathbf{R} & \mathbf{N} & \mathbf{A} & \mathbf{L}\end{array}$

0 F

$\begin{array}{llllll}P & \mathbf{U} & \mathrm{B} & \mathrm{L} & \mathbf{I} & \mathbf{C}\end{array}$

H $\quad$ E $\quad A \quad L \quad T \quad H$

\title{
Mid-upper arm circumference in pregnant women and its relation to birth weight*
}

\section{Perímetro braquial da gestante e sua relação com o peso ao nascer}

Anamaría E. Ricalde, G ustavo Velásquez-Meléndez, Ana Cristina d'A. Tanaka and Arnaldo A.F. de Siqueira

Departamento de Saúde Materno-Infantil da Faculdade de Saúde Pública da Universidade de São Paulo (FSP/U SP). São Paulo, SP - Brasil (A. E. R., A. C. A. T., A. A. F. S.), Departamento de Nutrição da FSP/U SP. São Paulo, SP - Brasil (G.V.M.) 


\title{
Mid-upper arm circumference in pregnant women and its relation to birth weight*
}

\section{Perímetro braquial da gestante e sua relação com o peso ao nascer}

\author{
Anamaría E. Ricalde, G ustavo Velásquez-Meléndez, Ana Cristina d’A. Tanaka and Arnaldo \\ A.F. de Siqueira \\ Departamento de Saúde Materno-Infantil da Faculdade de Saúde Pública da U niversidade de São \\ Paulo (FSP/USP). São Paulo, SP - Brasil (A. E. R., A. C. A. T., A. A. F. S.), Departamento de Nutrição \\ da FSP/USP. São Paulo, SP - Brasil (G.V.M.)
}

\begin{abstract}
Objective

In order to determine the relationship between some maternal anthropometric indicators and birth weight, crown-heel length and newborn's head circumference, 92 pregnant women were followed through at the prenatal service of hospital in S. Paulo, Brazil.

Material and Method

Results

Conclusion

The following variables were established for the mother: weight, height, midupper arm circumference, pre-pregnancy weight, gestational weight gain and Quetelet's index. For the newborn the following variables were recorded: birth weight, crown-heel length, head circumference and gestational age by Dubowitz's method.

Significant associations were noted between gestational age and newborn variables. In addition, maternal mid-arm circumference (MUAC) and prepregnancy weight were found to be positively correlated to birth weight $(r=0.399 ; r=0.378$, respectively). The multivariate linear regression shows that gestational age, mother's arm circumference and pre-pregnancy weight continue to be significant predictors of birth weight. On the other hand, only gestational age and mother's age was associated with crown-heel length. Similarly MUAC was significantly associated with crown-heel length ( $\mathrm{r}=$ $0.306 ; \mathrm{P}=0.0030)$.

Maternal mid-upper arm circumference is a potential indicator of maternal nutritional status. It could be used in association with other anthropometric measurements, instead of pre-pregnancy weight, as an alternative indicator to assess women at risk of poor pregnancy outcome.

Brachial perimeter. Pregnancy. Birth weight.

\section{Resumo}

Para determinar a relação entre os indicadores antropométricos maternos e o peso, a estatura e o perímetro cefálico do recém-nascido, foi realizado um estudo de seguimento de noventa e duas gestantes, inscritas no serviço de prénatal de um hospital de São Paulo, Brasil.
\end{abstract}

\footnotetext{
* Presented at "IV Congresso Brasileiro de Alimentação e Nutrição", São Paulo, 1996.

Correspondence to: Anamaría E. Ricalde - Av. Dr. Arnaldo, 715 - 01246-904 São Paulo, SP - Brasil.

E-Mail: acdatana@usp.br

The publication of this article was supported by FAPESP (Process n 97/09815-2).

Submitted on 14.4.1997. Reviewed 29.9.1997. Approved on 20.10.1997.
} 
Material e Método

Resultados

Conclusão
Foram estudadas as seguintes variáveis na mãe: peso, estatura, perímetro braquial, peso pré-gestacional, ganho de peso, idade e Índice de Quetelet. Nos recém-nascidos for am obtidas as seguintes variáveis: peso ao nascer, estatura, perímetro cefálico e idade gestacional pelo método de Dubowitz.

Foram observadas associações significativas entre a idade gestacional do recém-nascido e suas variáveis antropométricas. Adicionalmente, o perímetro braquial materno e o peso pré-gestacional estavam significativamente correlacionados com o peso ao nascer ( $r=0,399 ; r=0,378$ respectivamente). A regressão linear multivariada mostrou que a idade gestacional, o perímetro braquial materno e o peso pré-gestacional continuaram sendo preditores significativos do peso ao nascer. Somente a idade gestacional e a idade materna estiveram associadas com a estatura do recém-nascido, similarmente o perímetro braquial esteve associado com a estatura $(r=0,306 ; P=0,0030)$.

O perímetro braquial materno é um potencial indicador do estado nutricional materno. Poderia ser utilizado como indicador alternativo em substituição da estatura e peso pré-gestacional para avaliar mulheres em risco de ter um resultado da gravidez desfavorável.

Circunferência braquial. Gravidez. Peso ao nascer.

\section{INTRO DUCTION}

Pregnancy outcomes related to maternal nutritional status have been measured by anthropometry. Numerous research projects $9,14,17,19$ have studied maternal anthropometric indicators as predictors of birth weight. However, fewer of them have focused on the question as to which is the best indicator for the prediction of pregnancy outcomes with greater sensitivity, specificity and accuracy.

There are differences between developed and developing countries in determining the most appropriate cut-off points for anthropometric measurements ${ }^{5,13}$. Screening with measurements that require only one contact with a woman are useful due to limitations in available prenatal care in developing countries. To answer these questions some authors ${ }^{1,12}$ have studied the relationship between maternal mid-upper arm circumference (MUAC) and pregnancy outcome. They have shown that MUAC is a good indicator of pregnancy outcome.

The usefulness of MUAC for screening women at risk of poor pregnancy outcome is promising both on theoretical grounds ( it reflects maternal fat and / or lean tissue stores), because of the relationship between MUAC and weight $t^{1,6,12}$, and because it is independent of gestational age ${ }^{8,10}$.

In the present study we have analyzed the relationship between some maternal anthropometric indicators, including MUAC, and birth weight, crown-heel length and the head circumference of the newborn.

\section{MATERIAL AND METHOD}

The present study represents part of a sample of another study ${ }^{10}$ on anthropometric measurements in pregnant women. The subjects included in this study were women who received prenatal care and were delivered at the same hospital. Ninety-two pregnant women were covered and followed through during pregnancy. Their anthropometric indicators were recorded during the period from May 1991 to February 1992.

Measurements of height, weight, and mid-upper arm circumference (MUAC), were collected in accordance with standard recommendations. MUAC was measured at three different points during the pregnancy. Only the first measure was used for the analysis, because MUAC in this study did not vary during pregnancy. All the measurements were taken by the first author.

Women's pre-pregnancy weight was recorded at the first prenatal visit. Gestational weight gain was recorded on the basis of the difference between weight before delivery and pre-pregnancy weight. Quetelet's index (BMI) was also calculated in this study.

Subjects included in this study were non-smokers, non-consumers of alcoholic beverages and free of any obstetrical and medical complications known to affect fetal growth.

Only singleton term deliveries (38-42 weeks of gestation from last menstrual period and /or pediatric assessment of the gestational age) were included in the final analysis of the data.

The babies were free from congenital malformations 
and were clinically normal. The anthropometric measurements of these newborn were recorded within 24 hours of delivery by pediatricians trained at the same hospital.

The following variables were established for the newborn: birth weight, crown-heel length, head circumference and gestational age by Dubowitz's ${ }^{2}$ method.

\section{Statistical Analysis}

Frequency distributions or mean and standard deviations were calculated for all variables from a data base in a Dbase III program. For the statistical analysis, bivariate and stepwise forward multivariate linear regression were conducted in SPSS program. The dependent variables (birth weight, head circumference and crown-heel length) were examined for skewness and kurtosis using the normality test.

Since distribution of birth weight in this sample was not normal, natural log-transformations of birth weight and crude values were used to analyse the data, but only the model with crude values has been shown because the final conclusion is similar.

Initially, univariate associations between the dependent variables (birth weight, head circumference and crownheel length) and maternal anthropometric indicators (height, age, weight, gestational weight gain, arm circumference, pre-pregnancy weight) and gestational age as independent variables, were tested. The process of construction of the multivariate model consisted of the addition of the variables one at a time. If a variable was significantly associated or was a confounding variable it was included in the model until the best fit was found.

For all the statistical tests $\mathrm{P}<0.05$ was considered significant.

\section{RESU LTS}

The anthropometric characteristics of the population are shown in Table 1. Mean values (and standard deviations) of anthropometric measure- ments are presented both for the mothers and their newborn babies. Only $10 \%$ of the mothers were under 20 years of age. The frequency of low birth weight $(<2,500 \mathrm{~g})$ was $7.6 \%$.

Table 2 displays the correlation coefficients between mothers' and newborns' measurements. Generally there were significant correlations between the anthropometric variables of the mothers and the newborn, except for the correlation birth weight, newborn's crown-heel length and gestational weight gain and mother's height; and between newborn's head circumference and mother's arm circumference.

As expected, there were statistically significant associations between gestational age and birth weight, newborns' crown-heel length and head circumference $(r=0.425 ; r=0.309 ; r=0.265$, respectively). In addition, MUAC and pre-pregnancy weight were found to be positively correlated to birth weight ( $r=0.399 ; r=0.408)$ and the newborn's crownheel length $(r=0.306 ; r=0.376)$. Pre-pregnancy weight was less closely associated with the newborn's head circumference $(r=0.256)$.

The results of the multivariate linear regression models are shown in Tables 3-4. In the first model (Table 3$)$ gestational age $(\beta=135.48 ; \mathrm{P}=0.0001)$ and MUAC ( $\beta=45.52 ; \mathrm{P}=0.001)$ continue to be significant predictors of birthweight. Using the pre-pregnancy weight rather than MUAC as a predictor of birth weight, a second model was fitted (Table 4). Similarly, the gestational age $(\beta=138.39 ; p=0.0001)$ and pre-pregnancy weight $(\beta=16.064 ; \mathrm{p}=0.002)$ were positively correlated to birth weight; in this case, gestational weight gain was excluded because its inclusion did not improve the model.

For the model using the crown-heel length as the dependent variable only gestational age $(\beta=0.47$, $\mathrm{p}=0.0025)$ and mother's age $(\beta=0.083 ; \mathrm{p}=0.008)$ maintained an association (data not shown). To exa-

Table 1- Anthropometric characteristics of 92 pregnant women and their newborn children, S. Paulo-Brazil.

\begin{tabular}{lrc}
\hline Anthropometric characteristics & M ean & SD \\
\hline Mothers & & 6.59 \\
Age (years) & 27.00 & 9.88 \\
Pre-pregnancy weight (kg) & 55.83 & 4.01 \\
Gestational weight gain (kg) & 8.88 & 3.44 \\
Mid-upper arm circumference (cm) & 27.00 & 5.99 \\
Height (cm) & 156.74 & 3.93 \\
Q uetelet index (kg/m2) & 24.71 & 485.24 \\
Newborn & & 2.08 \\
Birth weight (g) & 3140.29 & 1.40 \\
Crown-heel length (cm) & 48.78 & 1.32 \\
Head circumference (cm) & 34.45 & 38.08 \\
Gestational age (weeks) & & \\
\hline
\end{tabular}

\footnotetext{
SD - Standard deviations.
} 
Table 2 - Correlation coefficients (and P- values) between anthropometric measurements in 92 pregnant women and their newborn children, S. Paulo-Brazil.

\begin{tabular}{|c|c|c|c|c|c|c|}
\hline \multirow{3}{*}{ Mothers' variables } & \multicolumn{6}{|c|}{ N ewborn variables } \\
\hline & \multicolumn{2}{|c|}{$\begin{array}{l}\text { Birth weight } \\
\text { (g) }\end{array}$} & \multicolumn{2}{|c|}{$\begin{array}{c}\text { Crown-heel length } \\
(\mathrm{cm})\end{array}$} & \multicolumn{2}{|c|}{$\begin{array}{l}\text { Head circumference } \\
(\mathrm{cm})\end{array}$} \\
\hline & $r$ & $P$ & $r$ & $P$ & $r$ & $P$ \\
\hline H eight $(\mathrm{cm})$ & 0.1990 & 0.058 & 0.205 & 0.052 & 0.218 & 0.038 \\
\hline Q uetelet index $(\mathrm{kg} / \mathrm{m} 2)$ & 0.364 & 0.000 & 0.329 & 0.001 & 0.299 & 0.029 \\
\hline Gestational age (w eeks) & 0.425 & 0.001 & 0.309 & 0.01 & 0.265 & 0.01 \\
\hline Gestational weight gain $(\mathrm{kg})$ & 0.158 & 0.135 & 0.131 & 0.052 & 0.210 & 0.045 \\
\hline Age (years) & 0.253 & 0.016 & 0.282 & 0.007 & 0.288 & 0.006 \\
\hline MUAC $(\mathrm{cm})$ & 0.399 & 0.000 & 0.306 & 0.003 & 0.176 & 0.094 \\
\hline Pre-pregnancy weight $(\mathrm{kg})$ & 0.378 & 0.000 & 0.094 & 0.001 & 0.256 & 0.014 \\
\hline
\end{tabular}

MUAC - mid-upper arm circumference

Table 3 - Multivariate linear regression model of some predictors of birth weight in 92 pregnant women, S. Paulo-Brazil.

\begin{tabular}{lrrr}
\hline Independent variables & B-coefficient & Seß & P-value \\
\hline MUAC (cm) & 45.52 & 13.38 & 0.001 \\
Height (cm) & 9.67 & 7.34 & $\mathrm{NS}$ \\
Gestational age (weeks) & 135.48 & 32.98 & 0.0001 \\
Gestational weight gain (kg) & 1.96 & 11.28 & $\mathrm{NS}$ \\
\hline
\end{tabular}

model: $r^{2}=0.312 \quad P$ model $=0.000$

NS- N ot significant

MUAC - mid-upper arm circumference

Table 4 - Multivariate linear regression model of some predictors of birth weight, with pre-pregnancy weight as independent variable instead of MUAC, S. Paulo-Brazil.

\begin{tabular}{lcrr}
\hline Independent variable & B-coefficient & SEß & P-value \\
\hline Pre-pregnancy weight (kg) & 16.064 & 5.07 & 0.002 \\
Gestational age (weeks) & 138.39 & 33.25 & 0.0001 \\
M other's height (cm) & 1.36 & 8.31 & NS \\
\hline
\end{tabular}

model: $r^{2}=0.29 \quad P$ model $=0.000$

NS- N ot significant

MUAC - mid-upper arm circumference

mine the possible determinants of newborn's head circumference, another model was created and the results showed that gestational age $(\beta=0.295$; $\mathrm{p}=0.005)$, mother's age $(\beta=0.07 ; \mathrm{p}=0.004)$ and gestational weight gain $(\beta=0.069 ; p=0.048)$ were significantly associated with the newborn's head circumference (data not shown).

\section{DISCUSSION}

As expected, gestational age was found to be related to birth weight, head circumference and crown-heel length. These results corroborate understanding that gestational age is a highly important factor in fetal size. The present data confirm numerous observations indicating that gestational age is a predictor of birth weight.

In this study an average increase of $135.48 \mathrm{~g}$ for infant birth weight (when the MUAC is included in the model) and of $138.39 \mathrm{~g}$ (when pre-pregnancy weight was controlled) were observed for each week of gestation; these results are similar to those obtained in another study also undertaken in Brazil ${ }^{18}$.

Gestational weight gain was not significantly associated with birth weight or with newborn's crown-heel length. Similarly Khan et al. ${ }^{4}$ found no correlation between pregnancy weight gain and birth weight $(r=0.06)$. The lack of association between these variables can be attributed to the fact that weight gain in pregnancy is independent of previous nutritional status. Wellnourished as well as undernourished or obese women can have high or low weight gains during pregnancy.

This study, as well as others published by Rush et al. ${ }^{11}$, demonstrated no correlation between maternal height and birth weight. Some studies demonstrated an association between short maternal height and low birth weight only ${ }^{3,14}$. In prenatal services, maternal height is more often used to determine the risk of cephalo-pelvic disproportion. Studies have demonstrated that height is associated with maternal pregnancy complications ${ }^{15}$.

Data on maternal MUAC show that this indicator 
is a significant predictor of birth weight. An increment of $45 \mathrm{~g}$ in birth weight can be expected for each additional $\mathrm{cm}$ in arm circumference measurement.

Several studies with different cut-off levels have demonstrated that MUAC is a good predictor of risk of low birth weight as compared with other classic anthropometric measurements ${ }^{7}$.

Recent studies have demonstrated that MUAC is closely related to maternal weight ${ }^{6,16}$ but is independent of gestational age ${ }^{8,10}$. Therefore MUAC should be used instead of pre-pregnancy weight to assess maternal nutritional status.

One advantage of using MUAC to assess women at nutritional risk of giving birth to low birth weight babies is that arm circumference measurements can be taken whenever a woman visits a health worker or health centre.

Since MUAC is a very simple technique, we recommend it, rather than pre-pregnancy weight, as a predictor of birth weight. The only difficulty that remains is that we can not recommend a cut-off level for MUAC, because the sample population of this study is too limited to establish it. In another study undertaken in Guatemala, a cut-off level of $23.5 \mathrm{~cm}$ has shown high sensitivity $(77 \%)$ and specificity (71\%) for the prediction of low birth weight ${ }^{8}$. However, more studies involving large samples are needed so as to enable the cut-off levels for MUAC with a view to determining the risk of developing poor pregnancy outcome to be established.

Therefore, MUAC could be considered as a potential indicator of maternal nutritional status, and may be used instead of pre-pregnancy weight, as an alternative indicator to assess women at risk of poor pregnancy outcome in communities where weighing is not feasible for pregnant women and/or when presentation for prenatal care is late.

\section{REFEREN CES}

1. ANDERSON, M. A. The relationship between maternal nutrition and child growth in rural India. 1989. [Ph. D. Dissertation, Tufts University].

2. DUBOWITZ, L.M.S. \& DUBOWITZ, V. Gestational age of the newborn. London, Adison-Wesley, 1977.

3. HUSAINI, Y. K.; HUSAINI, M.A.; SULAIMAN, Z.; JAHARI, A.B.; BARIZI; HUDONO, S.T.; KARYADI, D. Maternal malnutrition, outcome of pregnancy, and a simple tool to identify women at risk. Food Nutr. Bull., 8, 71-8, 1986.

4. KHAN, L.K.; HARRISON, G.G.; GALAL,O.M.; RITENBAUGH, CH.; SHAHEEN, F.M.; KIRSEY, A.; JEROME, N.W. Prevalence and functional correlates of obesity in an Egyptian village. Ecol. Food Nutr., 34: 311-25, 1996.

5. KRAMER, M. Determinants of low birth weight: methodological assessment and meta-analysis. Bull. World Health Organ., 65: 663-737, 1987.

6. KRASOVEC, K. An investigation into the use of maternal arm circumference for nutritional monitoring of pregnant women. Baltimore, 1989. [SC. D. Dissertation - Johns Hopkins University/School of Hygiene and Public Health].

7. KRASOVEC, K. Arm circumference: background issues. In: Krasovec, K.\& Anderson, M. A. ed. Maternal nutrition and pregnancy outcomes. Washington, D. C., Pan American Organization, 1991. p. 119-31 (PAHO - Scientific Publication, 529).
8. LECHTIG,A. Predicting risk of delivering low birth weight babies: which indicator is better? J. Trop. Pediatr., 34:34-41, 1988.

9. NAEYE, R. Weight gain and the outcome of pregnancy. Am. J. Obstet. Gynecol., 135: 3-9, 1979.

10. RICALDE, P. A. E. Contribuição para o estudo do perímetro braquial na avaliação do estado nutricional da gestante. São Paulo, 1994. [Dissertação de Mestrado - Faculdade de Saúde Pública, da USP]. Brasil.

11. RUSH, D.; DAVIS, H.; SUSSER, M. Antecedents of low birth weight in Harlem, New York City. Int. J. Epidemiol., 1, $375-87,1972$.

12. SHAH, A. Appropriate technology and perinatal ca-re: the Kasa experience. Adv. Int. Matern. Child Health, 2,:1-15, 1982.

13. SHAH, K. The evolution of the use of arm circumference for assessing maternal nutritional status. In: Krasovec, K.\& Anderson, M. A., ed. Maternal nutrition and pregnancy outcomes. Anthropometric assessment. Washington, D. C., Pan American Health Organization, 1991. p. 132-7 (PAHO Scientific Publication, 529).

14. SIQUEIRA, A.A.F. de; JUNIOR, C. C.; MARCONDES DE ALMEIDA, P.A.; TANAKA, A.C. d'A.; MONTELONE, P.P.R.; GONÇALVES de ARRUDA, J. de J.; DELASCIO, D. The influence of maternal height and weight gain and gestational age on the newborn's weight. Rev. Saúde Pública, 9, 331- 42, 1975. 
and fetal outcome. Indian Pediatr, 24: 703-12, 1987.

5. THOMSON, A. M. Maternal stature and reproductive efficiency. Eugen. Rev., 51: 157-62,1959.

16. TIBREWALA, S. \& SHAH, K. The use of arm circumference as an indicator of body weight in adult women. Baroda J. Nutr., 5: 43-5, 1978.

17. TRIPATHI, A.M.; AGARWAL, D.K.; DEVI, R.R.; CHERIAN, S. Nutritional status of rural pregnant women

18. VICTORA, C. G.; BARROS, F.C.; VAUGHAN, J.P. Epidemiologia da desigualdade: um estudo longitudinal de 6.000 crianças brasileiras. 2a ed. São Paulo, CEBES/HUCITEC, 1989.

19. WINIKOFF, B. \& DEBROVNER,C. Anthropometric determinants of birth weight. Obstet. Gynecol., 58: 678-84, 1981. 